for low-priced books, side by side but not in competition with the existing market for higher-priced books. They conclude that people will buy books that interest them, without too much regard for price (does this account for the \$10 price set on their own volume!).

The authors recommend that studies of this kind be repeated at intervals of a year or two. Librarians will agree that no one survey in this field can be regarded as definitive. Indeed, so fast have world events moved, that the data for this study, collected between May 21 and June 8, 1945, were obsolete before publication. They were gathered in the closing moments of the pre-atomic age, just after V-E Day, but before the bomb fell on Hiroshima. Moreover, they were obtained while millions of American men whose reading interests and habits are known to have been materially affected by their military experience were still overseas. Although some adjustment was made in the sampling quotas, no attempt was made to secure data from this large and influential group of readers. Nor is any reference made in the interpretation of the findings to relevant information about American service men gathered by others.

Compared with such studies as Wilson's Geography of Reading, Waples' People and Print, and Waples and Tyler's What People Want to Read About, the present survey cannot but appear superficial, especially with respect to interpretation of findings. The authors seem unaware that other studies of "people and books" have been conducted by highly competent investigators. They make no effort to relate their findings to those obtained in other surveys. In fact, they make no reference whatever to any of the literature in this field. The book is attractively printed and bound but contains neither bibliography nor index.-Alice I. Bryan.

\title{
Little Magazines
}

The Little Magazine: A History and a Bibliography. By Frederick J. Hoffman, Charles Allen, and Carolyn F. Ulrich. Princeton, Princeton University Press, 1946. ix, 440p.

Presumably, there could be no little magazines until first there were big ones. The authors of this book point out that the little magazine movement (if it may be called that) began about 1910. Its beginnings, then, coincide with the end of the muckraking era, which, if it did nothing else, established the permanent place in America of the popular, large-circulation magazine; the number of readers of Munsey's, McClure's, Everybody's increased by the hundreds of thousands under the pressure of new journalistic techniques, but when muckraking died the tremendous circulations remained and presently grew even larger. It seems more than a coincidence that in the second decade of the twentieth century the little magazine began to feed on a vigorous and sometimes ostentatious opposition to bigness.

Of this relationship, Hoffman-Allen-Ulrich make nothing at all. Instead, they point out a very creditable relationship to the later history of publishing; 80 per cent of the authors of literary worth in our time, they say, were first published in the little magazines. It is only fair to add, however, that they define "little" as something more than a matter of size. True, the little magazine lived a precarious, hand-to-mouth existence. Often its only subscribers were its contributors (particularly if you include "would-be" contributors). Sometimes it died a thousand deaths before its final collapse. And collapse, of course, it always did in the end, for if it lived on it was no longer to be considered a little magazine. But they make the further distinction that the little magazine published experimental writing and went in for the latest literary thing. Like a number of the editors they are writing about, they are inclined to prefer the term "advance guard" to "little." The distinction is useful though it may be argued.

In the history which makes up a good half of the volume, little magazines are divided into six classes-poetry, leftist, regional, experimental, critical, and eclectic. Chapters on each type are interspersed with chapters on the historical development of the genre. Some of the magazines to receive extended treatment are The Double Dealer, The Little Review, Poetry, The Seven Arts, Broom. The Partisan Review is presented as a little 
magazine that has grown into something else. The Sewanee Review, The Southern Review, The Kenyon Review, The Yale Review, and The Virginia Quarterly Review are described as "fellow travelers" of little magazines. Not mentioned at all, not anywhere in the book, are such magazines as The American Scholar, The Antioch Review, Science and Society.

Interesting as many of the details are in this section, its ineffective organization and incompleteness make it less important (and useful to librarians) than the latter half of the book, which is given over to a two-part bibliography-the much larger first part to little magazines, the second to the fellow travelers of little magazines-and a first-rate index. Reading the history section, for instance, leaves one quite unprepared to discover that of the 540 little magazines listed in the first bibliography, I 34 were published outside the United States-in such countries as England, France, Mexico, Australia, Ireland, Germany, Denmark, and Russia. (An even larger percentage of the fellow travelers are foreign, 43 out of a total of 96.)

The significance of the geographical spread of the little magazine becomes clearer when one examines the informative bibliographical notes under particular entries. Clearly one of the most important results of the little magazine - and in some instances it was an avowed purpose-was cultural interchange between the nations. Translations and critical estimates of foreign authors have been a frequent feature of the little magazine at all times in the last thirty-five years. Interestingly enough, the authors list the publication date of the first modern little magazine as I89I. They might well have made something of the fact that this was the year in which Congress passed the International Copyright Bill. For the act gave American literature a chance to come of age in relation to other literatures; American writers were freed from the frequent practice of foreign pirating and from the unfair competition that existed when foreign fiction and magazine articles could be republished here without the consent of the authors. The little magazine, more than any other part of the publishing industry, seems to have taken advantage of the opportunity. Be that as it may, cultural and literary interchange with other countries has been as much a mark of the little magazine as the publication of experimental writing.

Digging out the elusive facts about brief, fly-by-night journals published over half the world is not the easiest of tasks, and it was a foregone conclusion that a number would be missed. Yet I am sure of only one omission-The Wastebasket published in the Middle West (at St. Paul?) about the end of World War I. For the care of detail and intensive labor lavished on their bibliography, the authors (and presumably Miss Ulrich in particular) are to be congratulated. For the literary researcher and the librarian they have provided a wealth of material which should be useful for some time to come.-Paul Bixler.

\section{Books and Libraries in Wartime}

Books and Libraries in Wartime. Edited by Pierce Butler. Chicago, University of Chicago Press, 1945.

In the spring of 1944 ten lectures were delivered under the auspices of the Graduate Library School, University of Chicago, to describe the impact of war on libraries, books, the press, radio, and motion pictures. The volume under review, published a year and a half after the event, contains eight of the lectures, well-edited by Professor Butler. It is unfortunate that they did not appear in print earlier. Timeliness is of minor importance in presenting results of systematic research, but a collection of essays on current trends and events loses much of its value by delay in publication. The fact that some of the contributors did pay attention to postwar problems, however, renders publication at so late a date somewhat more justifiable.

To university and research librarians, the contributions by MacLeish, Beals, and Butler will be of greatest interest. MacLeish's statesmanlike address shows how vital research libraries are to the security of a free nation. Library materials should not serve any particular group but the entire generation of living men. Such an ideal is to be 